\title{
KETERKAITAN NEKROSIS INSANG LARVA TRICHOPTERA CHEUMATOPSYCHE sP. DENGAN KONTAMINAN LOGAM MERKURI: STUDI KASUS DI SUNGAI CILIWUNG DAN CIKANIKI
}

\author{
RELATIONSHIP OF NECROSIS GILLS CHEUMATOPSYCHE sp. \\ TRICHOPTERA LARVAE WITH MERCURY METAL CONTAMINATION: \\ CASE STUDY IN CILIWUNG AND CIKANIKI RIVER
}

Jojok Sudarso', Gunawan P. Yoga ${ }^{1}$

(Diterima tanggal 02-02-2016; Disetujui tanggal 06-03-2016)

\begin{abstract}
ABSTRAK
Keberadaan logam merkuri pada ekosistem akuatik telah diketahui banyak menimbulkan dampak negatif bagi biota perairan. Salah satu biota akuatik (organisme makrozoobentos) yang terkena dampak kontaminan logam merkuri adalah larva insekta Trichoptera Cheumatopsyche sp. Tujuan dari penelitian ini adalah untuk mendeskripsikan adanya korelasi antara meningkatnya kontaminan logam merkuri di perairan dengan persentase terjadinya nekrosis insang larva Cheumatopsyche sp. di Sungai Ciliwung dan Cikaniki. Larva Trichoptera dikumpulkan dengan menggunakan alat jala surber dan dilakukan penggabungan menjadi satu sampel (komposit). Hasil penelitian ini menunjukkan adanya korelasi yang kuat antara kontaminan logam merkuri di sungai dengan persentase nekrosis larva Cheumatopsyche sp. ( $r=0,8$ untuk sungai Cikaniki dan $\mathrm{r}=0,9$ untuk Sungai Ciliwung). Disamping itu ada kecenderungan bioakumulasi logam merkuri di tubuh larva Cheumatopsyche sp. diikuti dengan meningkatnya kejadian nekrosis pada insang ( $\mathrm{r}=0,8$ untuk sungai Cikaniki dan $\mathrm{r}=0,88$ untuk sungai Ciliwung). Penelitian ini menunjukkan potensi yang besar dari penggunaan insang larva Cheumatopsche sp. sebagai indikator terhadap stress oleh kontaminan toksik lainnya di ekosistem akuatik.
\end{abstract}

Kata kunci: toksisitas kronis, logam berat, larva, bioindikator, bioakumulasi

\begin{abstract}
Mercury contamination in aquatic ecosystems has been reported to give many negative impacts for freshwater organisms. Cheumatopsychesp. (Trichoptera) is one of aquatic biota (macrozoobenthos organisms) affected by mercury contamination. The purpose of this study was to show a correlation between increasing mercury contamination in Ciliwung and Cikaniki rivers, with percentage of gill necrosis incidence in Cheumatopsyche sp. larvae. Trichoptera larvae was collected using Surber net and was composited. The results of this study showed a strong correlation between mercury contamination in the river with the percentage of larvae necrosis Cheumatopsyche $\mathrm{sp} .(\mathrm{r}=0.8$ for Cikaniki and $\mathrm{r}=0.9$ for Ciliwung). Besides, there was a tendency in the presence of metal bioaccumulation of mercury in the body of the larvae Cheumatopsyche sp.followed by the increasing incidence of necrosis in the gills ( $\mathrm{r}=0.8$ for Cikaniki and $\mathrm{R}^{2}=0.88$ for Ciliwung river). Gill necrosis of Cheumatopsche sp. larvae has great potency tobe used as indicator of the contamination of other toxic pollutants in aquatic ecosystems.
\end{abstract}

Keywords:chronic toxicity, heavy metal, larva, bioindicator, bioaccumulation.

\section{PENDAHULUAN}

Kontaminan logam berat di ekosistem perairan telah dilaporkan banyak menimbulkan dampak negatif bagi biota akuatik. Beberapa respon dari biota akuatik terhadap adanya kontaminan logam antara lain: kecacatan bagian mulut pada larva Chironomid [1], nekrosis pada insang dan penyimpangan pola pembentukan sarang dari larva Trichoptera

\footnotetext{
${ }^{1}$ Puslit Limnologi LIPI, Jl. Raya Jakarta-Bogor km 46, Cibinong, 16911, Kab. Bogor, (e-mail: denmaskoyoy@hotmail.com).
} 
[2];[3], maupun pembentukan enzim stress $[4] ;[5]$.

$$
\text { P engguna a organism e }
$$
makrozoobentos seperti larva Trichoptera sebagai indikator biologi perairan telah banyak mendapat perhatian para peneliti. Hal ini disebabkan larva tersebut memiliki beberapa keuntungan antara lain: a). Salah satu penyusun terbesar dari komunitas makrozoobentos pada ekosistem sungai, b). Distribusi yang luas, c). Kelimpahan yang relatif tinggi, d). Respon terhadap kualitas lingkungan bervariasi dari mulai perubahan morfologi, kemampuan akumulasi bahan polutan, hingga perubahan perilaku [5], e). Keanekaragaman spesies yang relatif tinggi hingga \pm 13.000 spesies [6]. 89 spesies Trichoptera telah diketahui hidup di Sulawesi Utara [7], f). Siklus hidup relatif panjang dengan lima tahap instar, g). Peran penting dalam rantai makanan sebagai dekomposer dan mangsa bagi burung maupun ikan, h). Ukurannya yang relatif besar (1-3 cm) dengan berat mencapai 30-100 mg, sehingga waktu untuk identifikasi hewan relatif lebih singkat, i). Tubuh relatif keras sehingga memudahkan dalam melihat abnormalitas/ kecacatan [8].

Logam merkuri termasuk jenis logam yang sangat beracun dan memiliki kemampuan untuk terakumulasi pada makhluk hidup dan biomagnifikasi pada rantai makanan. Keberadaan logam merkuri terdapat di seluruh alam namun distribusinya tidak merata. Emisi global merkuri yang dilepaskan ke lingkungan dari aktivitas antropogenik tahun 2005 diperkirakan mencapai 1930 ton dengan rincian 45,6\% dari pembakaran bahan bakar fosil, 18,2\% dari penambangan emas, 10,4 \% dari produksi logam, dan $9,8 \%$ dari produksi semen dan lain-lain [9]. Di tahun 2010 emisi global merkuri yang dilepaskan ke atmosfer mencapai 1960 ton [27]. Kandungan merkuri dalam air tanah berkisar 0,01 - 0,07 ppb, sungai dan danau 0,08-0,12 ppb, tanah $30-$ $500 \mathrm{ppb}$, dan dalam batuan vulkanik antara 10100 ppb [9]. Konsentrasi merkuri anorganik yang menyebabkan toksisitas akut terhadap biota avertebrata berkisar antara 5 hingga 5600 $\mu \mathrm{g} \mathrm{Hg} / \mathrm{L}$, sedangkan terhadap ikan berkisar antara 150 hingga $900 \mu \mathrm{g} \mathrm{Hg} / \mathrm{L}$. Toksisitas kronis merkuri di avertebrata memiliki sensitivitas hampir sama dengan di ikan. Konsentrasi merkuri anorganik yang dapat menimbulkan efek (Effect concentration, $\mathrm{EC}_{50}$ ) pada avertebrata berkisar antara 1,28 sampai 12,0 $\mu \mathrm{g} \mathrm{Hg} / \mathrm{L}$. Pada ikan, nilai kronik untuk merkuri anorganik berkisar antara 0,26 sampai $>64 \mu \mathrm{g} \mathrm{Hg} / \mathrm{L}[10]$.

Lokasi penelitian dipilih Sungai Cikaniki dan Ciliwung yang merupakan dua sungai besar di Propinsi Jawa Barat. Sungai Cikaniki merupakan anak sungai dari Sungai Cisadane. Kedua sungai tersebut memiliki arti penting bagi masyarakat Jabodetabek karena memiliki multifungsi antara lain: sebagai sumber bahan baku air bersih, pertanian, perikanan, industri dan sebagainya. Kontaminan logam merkuri di kedua sungai tersebut diduga dihasilkan dari keberadaan aktivitas penambangan emas tanpa ijin (PETI), point sources (limbah industri dan rumah tangga), maupun sumber non point sources lainnya (pertanian, transpotasi, atmosferik, dan sebagainya). Hasil pengamatan yang dilakukan oleh Sudarso [11] menunjukkan konsentrasi logam merkuri di air Sungai Ciliwung dari mulai 0,03-3,55 ppb dan sedimen sebesar (4,46-125,3 ppb). Konsentrasi logam merkuri pada anak sungai 
Cikaniki dapat mencapai 0,005-0,039 ppm [12].

Tujuan dari penelitian ini adalah untuk mendeskripsikan adanya korelasi antara meningkatnya kontaminan logam merkuri di perairan dengan persentase insiden nekrosis insang larva Cheumatopsyche sp. di sungai Ciliwung dan Cikaniki.

\section{BAHAN DAN METODE}

Penelitian ini dilakukan pada bulan Oktober 2010-Mei 2012 di dua lokasi pemantauan sungai yaitu: Ciliwung dan Cikaniki. Masing-masing sungai terdiri dari dua stasiun. Stasiun pertama merupakan lokasi kontrol yang diperkirakan mengalami gangguan minimal dari aktivitas antropogenik, sedangkan stasiun kedua merupakan situs uji yang telah mengalami gangguan oleh aktivitas antropogenik (misalnya rumah tangga, industri, pertanian dan sebagainya). Pemilihan lokasi sampling juga didasarkan pada kesamaan kondisi ekoregion yang termasuk dalam gradien tinggi dengan karakteristik banyaknya substrat batuan cobble ( $\Phi$ 64-256 mm) lebih dari 30\% dan kecepatan arus lebih dari 0,5 $\mathrm{m} /$ detik [13]. Pengambilan larva Trichoptera dilakukan dibagian litoral yang masih didominasi oleh batuan dan kondisi air sungai relatif stabil (tidak banjir). Larva Trichoptera dikumpulkan dengan menggunakan alat jala surber (berukuran $30 \times 30 \mathrm{~cm}^{2}$ dengan lebar mata jaring 0,2 $\mathrm{mm}$ ) yang dilakukan lima kali ulangan untuk setiap stasiun pengamatan. Pengambilan sampel larva Trichoptera dilakukan sebulan sekali. Hewan yang tertahan dalam saringan kemudian dilakukan penggabungan dengan lainnya hingga menjadi satu sampel (komposit).

Lokasi yang digunakan selama penelitian di Sungai Ciliwung dan Cikaniki dapat dilihat dalam Tabel 1. Peta lokasi pengambilan sampel sesuai dalam Gambar 1 . Jala surber dipasang di atas permukaan batu selama tiga menit dan disikat dengan menggunakan sikat gigi halus yang sudah dibersihkan, sehingga hewan yang masih menempel di batu akan terbawa hanyut masuk ke jala surber. Sampel dimasukkan dalam kantung plastik dan dimasukkan dalam box sampler yang telah diberi es batu sebagai pengawetnya. Identifikasi larva Cheumatopsyche sp. merujuk pada buku identifikasi [14].

Sampel larva Trichoptera Cheumatopsyche sp. untuk tujuan analisis logam merkuri dilakukan dengan cara larva dicuci dengan air destilasi deionisasi selama dua jam, kemudian dikeringkan diatas kertas saring/tisu. Larva dikering-bekukan selama 36 jam dalam refrigerator dan kemudian digerus dalam

Tabel 1. Lokasi sampling di sungai Ciliwung dan Cikaniki

\begin{tabular}{|c|c|c|c|}
\hline No & Sungai Ciliwung & No & Sungai Cikaniki \\
\hline 1 & $\begin{array}{l}\text { Gunung mas (lokasi kontrol) } \\
6^{0} 42^{\prime} 4,38^{\prime \prime} \text { LS, 106'58'12,49"BT }\end{array}$ & 1 & $\begin{array}{l}\text { Cikuluwung (lokasi kontrol) } \\
6^{\circ} 41^{\prime} 43,9 \text { " LS ; } 106^{\circ} 40^{\prime} 25,4 \text { " } \\
\text { BT }\end{array}$ \\
\hline 2 & $\begin{array}{l}\text { Cibinong (situs uji) } \\
6^{0} 28^{\prime} 58,55^{\prime \prime} \text { LS, } \\
106^{\circ} 48^{\prime} 53,05^{\prime \prime B T}\end{array}$ & 2 & $\begin{array}{l}\text { Lukut (situs uji) } \\
6^{\circ} 34^{\prime} 47,85^{\prime \prime} \text { LS; } 106^{\circ} 32^{\prime} 51,56^{\prime \prime} \\
\text { BT }\end{array}$ \\
\hline
\end{tabular}




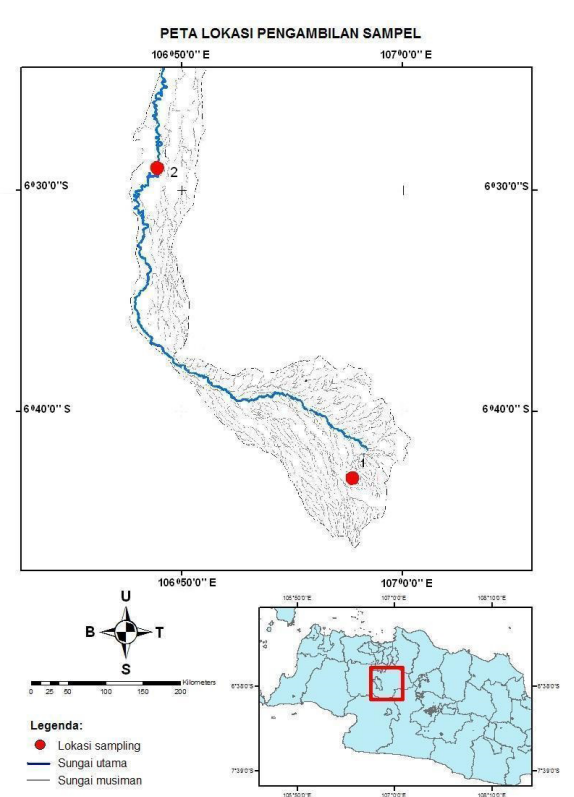

(a)

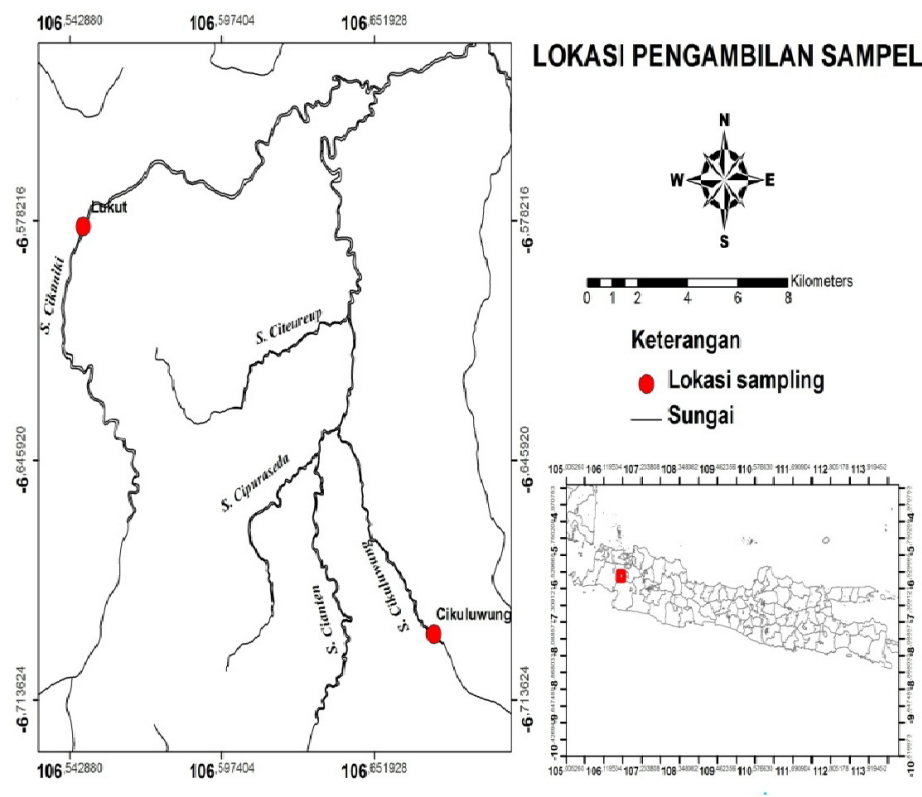

(b)

Gambar 1. Lokasi pengambilan sampel pada sungai Ciliwung (a) dan sungai Cikaniki (b).

mortar hingga menjadi bentuk tepung dan siap untuk dilakukan analisis lebih lanjut. Larva dipindah ke dalam cawan petri kemudian dimasukkan dalam refrigerator.

Pengukuran logam merkuri total pada larva Trichoptera dengan cara menimbang 0,5 gram larva yang sudah dihaluskan dimasukkan dalam tabung reaksi $(50 \mathrm{ml})$ kemudian ditambahkan air deionisasi sebanyak $1 \mathrm{ml}, 2$ $\mathrm{ml} \mathrm{HNO} . \mathrm{HClO}_{4}(1: 1)$, dan $5 \mathrm{ml} \mathrm{H}_{2} \mathrm{SO}_{4}$ pekat secara berurutan, kemudian dipanaskan pada suhu $200^{\circ} \mathrm{C} \pm 5^{\circ} \mathrm{C}$ selama 30 menit. Sampel didinginkan dan volume diatur hingga $50 \mathrm{ml}$ air deionisasi. Sampel diukur dengan menggunakan alat mercury analyzer sistem spektofotometer serapan atom (AAS) dengan sistem uap dingin (cold vapor) dengan metode sirkulasi aliran udara otomatis [15]; [16].

Sampel air yang akan dianalisis logam merkuri totalnya diambil dengan menggunakan botol kaca yang bervolume 1 liter. Sampel air disaring dengan menggunakan kertas saring GF/F glass microfiber $(0,7 \mu)$ lalu ditambah dengan $1 \mathrm{ml} \mathrm{H}_{2} \mathrm{SO}_{4}, 1 \mathrm{ml} \mathrm{HNO}_{3}, 2 \mathrm{ml} \mathrm{KMNO}{ }_{4}(50 \mathrm{~g} / \mathrm{L})$ dan $1 \mathrm{ml} \mathrm{K} \mathrm{S}_{2} \mathrm{O}_{8}(80 \mathrm{~g} / \mathrm{L})$ selanjutnya dipanaskan pada suhu $95^{\circ} \mathrm{C}$ selama 2 jam. Sisa $\mathrm{KMnO}_{4}$ dipisahkan dengan hydroxylaminchloride (10 \%) yang selanjutnya dilarutkan menjadi $50 \mathrm{ml}$ dengan labu ukur. Konsentrasi merkuri dalam larutan diukur dengan Mercury Analyzer HiranumaHg-300 [15];[17].

Fenomena nekrosis pada insang abdominal larva Cheumatopsyche sp. dapat dikenali dengan adanya penghitaman warna atau abrasi pada cabang insang. Insang dalam kondisi normal akan tampak bewarna putih bening [3].

Hubungan antara kontaminan logam merkuri di air sungai (X1) dan akumulasi logam di tubuh larva (X2) dengan persentase nekrosis pada insang (Y) di analisis dengan menggunakan statistik regresi sederhana. Analisis regresi sederhana dilakukan dengan menggunakan program software Statistica versi 10 (Statsoft). 


\section{HASIL DAN PEMBAHASAN}

Hasil dari kelimpahan rerata dari larva Chuematopsyche sp. dan persentase larva tersebut yang mengalami nekrosis pada insang dapat dilihat dalam Tabel 2. Bentuk dari nekrosis berupa penghitaman warna dari insang larva Cheumatopsyche sp. ditampilkan dalam Gambar 3. Dari Tabel 2 dapat diketahui bahwa kelimpahan tertinggi Larva Cheumatopsyche sp. dijumpai pada Sungai Ciliwung dibandingkan Cikaniki. Di lokasi kontrol kelimpahan larva di Stasiun Gunung Mas lebih tinggi dibandingkan Cikuluwung dengan persentase kejadian nekrosis 0\%. Di bagian situs uji menunjukkan kelimpahan larva Cheumatopsyche di Stasiun Cibinong lebih tinggi dibandingkan dengan Stasiun Lukut . Di Stasiun Cibinong dan Lukut mulai banyak terlihat aktivitas antropogenik di sekitar daerah tangkapan sungai. Persentase nekrosis di Stasiun Cibinong jauh lebih rendah $(4,16 \%)$ dibandingkan dengan Stasiun Lukut $(56,6 \%)$.

Hasil analisis logam merkuri di air sungai (Tabel 2) menunjukkan konsentrasi logam merkuri di Sungai Cikaniki relatif lebih tinggi dibandingkan dengan Sungai Ciliwung. Konsentrasi logam merkuri di lokasi kontrol menunjukkan Stasiun Lukut lebih tinggi dibandingkan dengan Stasiun Gunung Mas hingga 10 kali lipat. Antara situs uji menunjukkan kontaminan logam merkuri di Stasiun Lukut hingga 65 kali lipat dibandingkan Stasiun Cibinong.

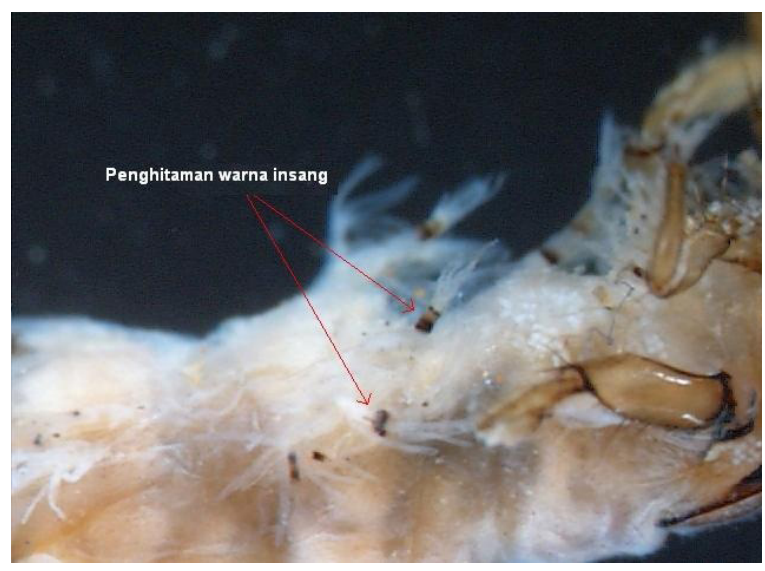

Gambar 3. Nekrosis pada insang abdominal larva Cheumatopsyche sp. di Stasiun Cibinong. Tanda panah menunjukkan lokasi terjadinya nekrosis. Pembesaran $80 \mathrm{X}$.

Hasil keterkaitan antara kontaminan logam merkuri di sungai dengan besarnya prosentase nekrosis di insang telah ditampilkan dalam Gambar 4. Hasil analisis regresi sederhana antara kontaminan logam merkuri di air dengan persentase nekrosis insang didapatkan persamaan $\mathrm{y}=6,9(\mathrm{X} 1)-11$ untuk sungai Ciliwung dengan nilai $\mathrm{p}=0,002, \mathrm{r}=0,9$, dan koefesien determinasi adjusted $\left(\mathrm{R}^{2}\right)=0,8$. Sedangkan untuk persamaan model kedua (Sungai Cikaniki ) adalah $\mathrm{y}=0,28(\mathrm{X} 1)+22,6$ dengan nilai $\mathrm{p}=0,000007, \mathrm{r}=0,8$, dan koefesien determinasi adjusted $\left(\mathrm{R}^{2}\right)=0,62$. Hasil pengolahan data secara statistik menunjukan adanya korelasi yang sangat erat antara peningkatan konsentrasi merkuri di air dengan meningkatnya prosentase

Tabel 2. Kelimpahan rerata dan persentase nekrosis insang larva Cheumatopsyche sp.

\begin{tabular}{ccccc}
\hline No & Stasiun & $\begin{array}{c}\text { Kelimpahan } \\
\text { rerata }\left(\mathrm{idv} / \mathrm{m}^{2}\right)\end{array}$ & \% nekrosis & $\begin{array}{c}\text { Konsentrasi Merkuri } \\
(\mathrm{ppb}) \pm \mathrm{SD}\end{array}$ \\
\hline 1 & Gunung mas & 31 & 0 & $0,07 \pm 0,03$ \\
2 & Cikuluwung & 3 & 0 & $2,34 \pm 0,63$ \\
3 & Cibinong & 370 & 4,16 & $0,73 \pm 14,1$ \\
4 & Lukut & 95 & 56,60 & $154 \pm 90,21$ \\
\hline
\end{tabular}


nekrosis di insang larva Trichoptera jenis Cheumatopsyche sp.

Hubungan antara akumulasi logam $\mathrm{Hg}$ di tubuh larva (X2) dengan nekrosis di insang (y) (Gambar 5) di kedua sungai juga menunjukkan korelasi yang sangat erat $(\mathrm{r}=0,8$ untuk Ciliwung dan $r=0,88$ untuk Cikaniki ). Persamaan regresi untuk nekrosis di sungai Ciliwung adalah y $=1,059(\mathrm{X} 2)+0,8$, dengan nilai $\mathrm{p}=0,000007, \mathrm{r}=0,8$, dan koefesien determinasi adjusted $\left(\mathrm{R}^{2}\right)=0,8$ sedangkan persamaan nekrosis ke dua (Sungai Cikaniki) adalah $\mathrm{y}=0,29(\mathrm{X} 2)+16,24$ dengan nilai $\mathrm{p}=0,00000002, \mathrm{r}=0,88$, dan koefesien determinasi adjusted $\left(\mathrm{R}^{2}\right)=0,7$. Kondisi ini mengindikasikan pengaruh akumulasi logam $\mathrm{Hg}$ dalam tubuh larva terhadap nekrosis insang di Sungai Cilakini sebesar 70\%, sedangkan $30 \%$ dipengaruhi oleh faktor lainnya. Oleh sebab itu semakin meningkatkan kandungan akumulasi $\mathrm{Hg}$ dalam tubuh Larva Cheumatopsyche akan diimbangi dengan semakin banyaknya persentase larva yang mengalami nekrosis pada insang.

Kelimpahan larva Cheumatopsyche sp.

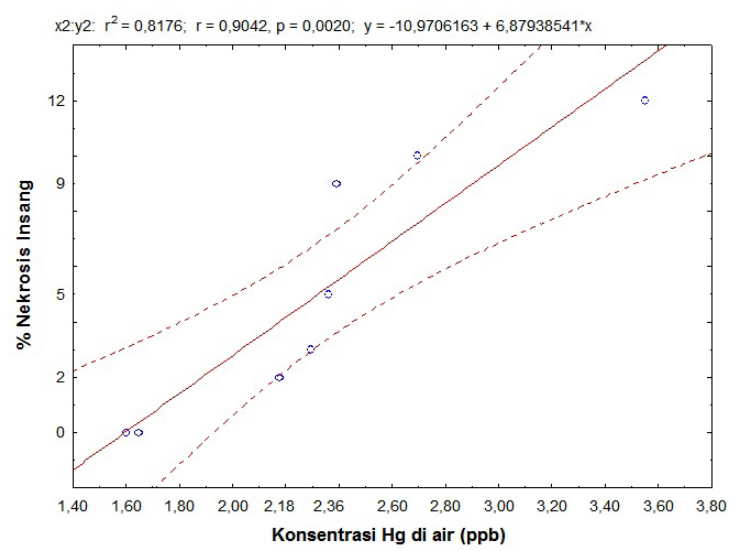

(a) di Sungai Ciliwung relatif lebih tinggi dibandingkan dengan Sungai Cikaniki. Kondisi ini mungkin erat kaitannya dengan kontaminan logam merkuri di sungai Ciliwung yang jauh lebih rendah jika dibandingkan Sungai Cikaniki. Tabel 2 menujukkan konsentrasi merkuri di Sungai Ciliwung dari Stasiun Gunung Mas (0,07 ppb) hingga Cibinong (2,34 ppb) dan Sungai Cikaniki dari Cikuluwung (0,73 ppb) hingga Lukut (154 ppb) meningkat secara drastis. Kondisi yang sama juga diamati oleh Barata et al. [4] yang menunjukkan kontaminan logam di sungai umumnya lebih tinggi di bagian hilir dibandingkan dengan hulu. Konsentrasi logam merkuri di Sungai Ciliwung dan Cikaniki tergolong relatif tinggi dan patut untuk diwaspadai. Baku mutu US-EPA untuk logam merkuri guna melindungi kehidupan hewan akuatik dari pengaruh akut sebesar 2,4 ppb dan 0,0012 ppb untuk pengaruh kronis [18]. Didasarkan pada konsentrasi tersebut di atas, maka keberadaan logam merkuri di Sungai Ciliwung dan Cikaniki berpotensi menimbulkan gangguan bagi biota akuatik yang hidup di dalamnya. Berdasarkan PP No

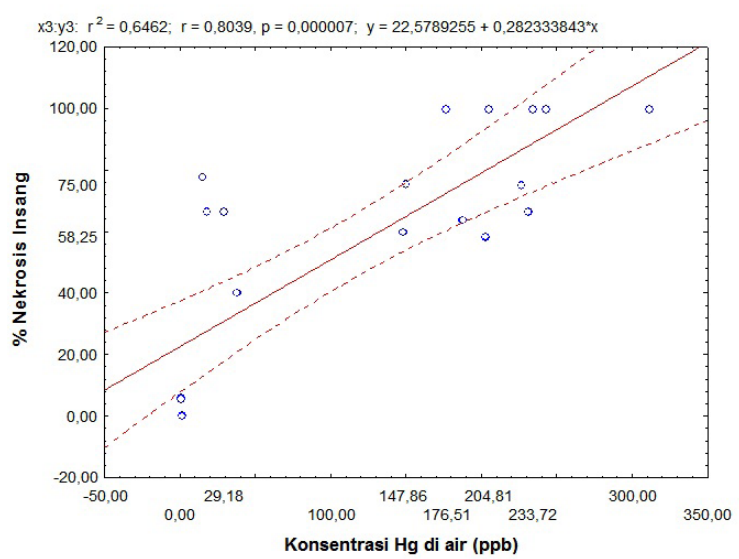

b)

Gambar 4. Keterkaitan antara persentase nekrosis di insang larva Cheumatopsyche sp. dengan konsentrasi logam di air sungai a) Ciliwung dan b) Cikaniki . Keterangan (------) merupakan garis persamaan regresi dalam model yang telah diatur, sedangkan (- - -) merupakan confidence interval regresi $(\alpha=5 \%)$. 


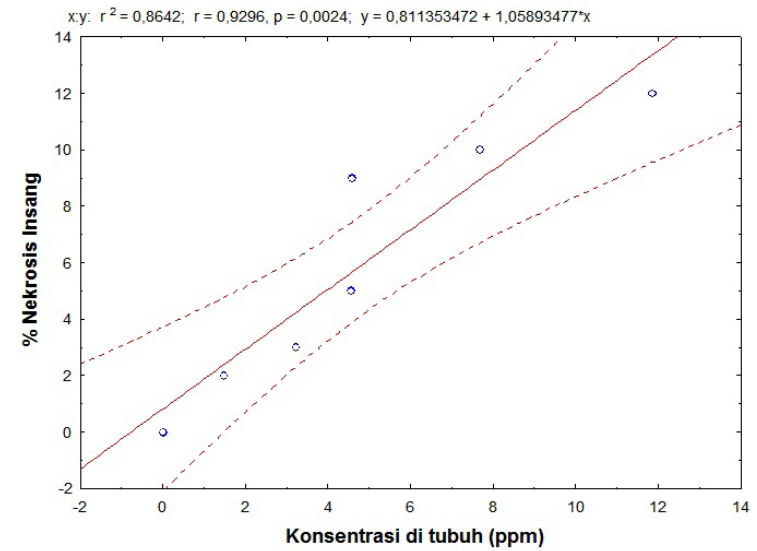

(a)

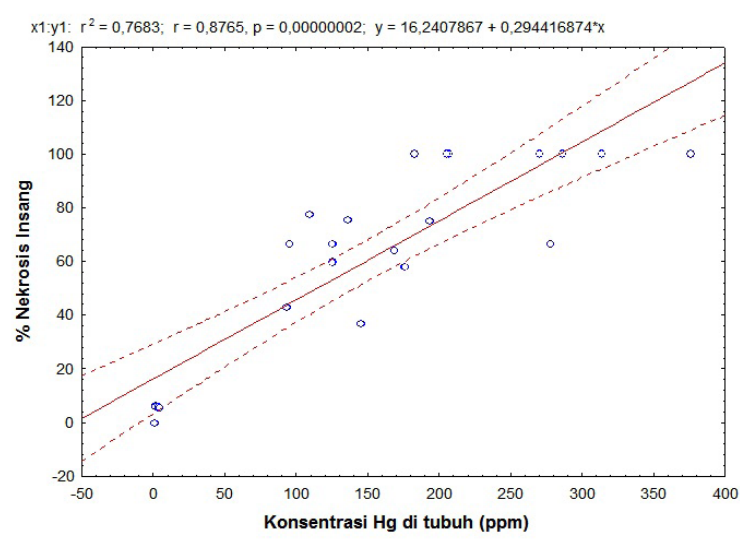

b)

Gambar 5. Keterkaitan antara persentase nekrosis di insang larva Cheumatopsyche sp. dengan akumulasi logam merkuri di dalam tubuh larva a). Ciliwung dan b). Cikaniki .

82 tahun 2001 tentang Pengeloaan Kualitas Air dan Pengendalian Pencemaran Air, maka di stasiun Cibinong dan Lukut telah melampaui kelayakan kelas mutu air golongan I dan II (0,001 ppm).

Tingginya kontaminan logam merkuri di sungai Cikaniki sebagian besar disebabkan oleh penggunaan logam tersebut selama proses amalgamasi guna memisahkan emas dari campuran pasir dan tanah. Diperkirakan 4,8 ton larutan merkuri yang telah digunakan oleh penambang emas tanpa ijin (Peti) di Sungai Cikaniki selama proses amalgamasi. Data dari Kabupaten Bogor tahun 1999 menunjukkan jumlah PETI yang melakukan penambangan emas di ruas Cikaniki mencapai jumlah 6000 orang [19]. Kondisi ini akan meningkatkan kandungan merkuri di Sungai Cikaniki-Cisadane. Kontaminan logam merkuri di Sungai Ciliwung kemungkinan besar dihasilkan dari difusi pembakaran bahan bakar fosil, pelindihan dari lahan pertanian, dan limbah industri dan perkotaan yang masuk ke saluran pembuangan hingga ke Sungai Ciliwung. Pengaruh jalur atmosferik juga mampu menyumbang kontaminan logam merkuri di perairan [27]. Flux emisi merkuri di udara secara global pada kondisi alami dapat mencapai $6 \mathrm{~g} / \mathrm{km}^{2} /$ tahun atau $0,7 \mathrm{ng} /$ $\mathrm{m}^{2} /$ jam [20]. Diperkirakan merkuri yang dilepaskan oleh kegiatan industri pertahunnya ke atmosfer sebesar 2905 ton [29]. Logam merkuri yang dilepaskan ke lingkungan selama proses amalgamasi di seluruh dunia diperkirakan mencapai 400-500 metrik ton per tahunnya. Kandungan merkuri pada minyak mentah berkisar dari $<1 \mathrm{ppb}$ hingga lebih dari 1000 ppm yang tergantung pada lokasi sumur pengeborannya[27]. Hasil analisis logam merkuri pada air hujan yang dilakukan selama penelitian di Cibinong menunjukkan konsentrasinya $0,07 \mathrm{ppb}$ [28]. Kondisi ini menandakan kontaminan logam merkuri melalui jalur atmosferik berpotensi juga menyebabkan kontaminasi di daerah lokasi kontrol (Gunung Mas dan Cikuluwung) yang minimal mendapatkan gangguan dari aktivitas antropogenik.

Hubungan antara abnormalitas insang makrozoobentos dengan kontaminan logam merkuri telah dipelajari oleh Skinner \& Bennett [3]. Peneliti tersebut menunjukkan 
adanya keterkaitan antara akumulasi logam merkuri (0,02 ppm) di tubuh makrozoobentos dan 9,8 ppb metilmerkuri di air dengan kejadian abnormalitas insang abdominalnya yang mencapai 28\%. Keberadaan logam merkuri di tubuh larva Cheumatopsyche sp. menunjukkan bioavailabilitas logam tersebut di perairan yang berpotensi menimbulkan gangguan untuk emergence menjadi dewasa. Pemaparan logam merkuri ke larva Hydropsychid mungkin berasal dari air sungai telah terkontaminan maupun melalui jalur makanan $[3 ; 25]$. Penghitaman warna insang merupakan sinyal awal gangguan fungsi respirasi maupun pengaturan ion. Perubahan morfologi insang hydropsychid berupa penghitaman warna, reduksi anal papilae, dan insang abdominal terlihat ketika larva dipaparkan logam kadmium, tembaga, aluminium, chromium, dan air terklorinasi. Munculnya penghitaman warna dan kelainan pada insang sering dijumpai pada instar terakhir atau lebih tua $[2 ; 21]$.

Larva Trichoptera memiliki jenis insang trakea dan sangat peka terhadap pengaruh toksisitas logam, karena afinitasnya yang tinggi dalam membentuk ikatan gugus sulfur dan nitrogen. Ikatan kimia yang terbentuk akan berpengaruh penting pada fungsi normal metaloenzim dan metabolisme sel. Ketika metaloenzim disubstitusi oleh logam yang bukan semestinya, menyebabkan protein mengalami deformasi dan mengakibatkan kemampuan enzim katalitik menurun [22]. Dampak lebih lanjut adalah terganggunya sistem biokimiawi hingga perubahan dalam struktur morfologi insang. Kematian dari biota dapat terjadi akibat anoxemia (terhambatnya fungsi sirkulasi dan ekskresi di insang). Kerusakan pada sistem pernafasan juga menyebabkan terhambatnya sistem transportasi elektron dan fosforilasi oksidatif pada penguraian makanan yang pada akhirnya akan berpengaruh pada metabolisme dan pertumbuhan. Logam berat yang diketahui memiliki pengaruh terhadap insang antara lain: timah hitam, seng, besi, tembaga, kadmium dan merkuri [23;24].

\section{SIMPULAN}

Hasil dari penelitian ini dapat disimpulkan bahwa meningkatnya konsentrasi logam merkuri di sungai Ciliwung dan Cikaniki menunjukkan adanya keterkaitan yang sangat erat dengan meningkatnya persentase nekrosis insang larva Trichoptera jenis Cheumatopsyche sp. Fenomena yang sama juga terjadi ketika kandungan merkuri dalam tubuh larva semakin meningkat, maka diikuti dengan kenaikan persentase nekrosis pada larva Trichoptera.

\section{UCAPAN TERIMA KASIH}

Penulis mengucapkan terima kasih pada Puslit Limnologi-LIPI yang telah mengijinkan melakukan penelitian di Laboratorium Ekotoksikologi dan Kementrian Ristek yang telah membiayai penelitian ini hingga selesai. Tak lupa penulis juga mengucapkan banyak terima kasih pada sdri. Rosidah yang telah membantu dalam analisis logam merkuri dan pada semua pihak yang banyak memberikan kontribusi pada penulis secara langsung maupun tidak. 


\section{DAFTAR PUSTAKA}

(1) Al-Shami S. A., Salmah M.R.C., Hassan A.A., and Azizah M.N.S. 2014. Fluctuating Asymmetry of Chironomus spp. (Diptera: Chironomidae) Larvae in Association with Water Quality and Metal Pollution in Permatang Rawa River in the Juru River Basin, Penang, Malaysia.Water Air Soil Pollut. DOI 10.1007/s11270010-0528-4.

(2) Chakona A., Phiri C., and Day J.A. 2009. Potential for Trichoptera Communities as Biological Indicators of Morphological Degradation in Riverine System.Hydrobiologia 621:155-167.

(3) Skinner K.M, and Bennett J.D. 2007. Altered Gill Morphology in Benthic Macroinvertebrates from Mercury Enriched Streams in the Neversink Reservoir Watershed. New York. Ecotoxicology 16: 311-316.

(4) Barata C., Lekumberri I., Vila-escale M., Prat N., and Porte C.. 2005. Trace metal concentration, antioxidant enzyme activities and susceptibility to oxidative stress in the tricoptera larvae Hydropsyche exocellata from the Lobregat river basin (NE Spain). Aquatic Toxicology 74: 3-19.

(5) Sola C., and Prat N. 2006. Monitoring Metal and Metalloid Bioaccumulation in Hydropsyche (Trichoptera, Hydropsychidae) to Evaluate Metal Pollution in a Mining River, Whole Body Versus Tissue Content.Science of the Total Environment 359: 221231.

(6) Holzenthal R.W. 2009. Trichoptera. Di dalam: Encyclopedia of Limnology. Netherland. Elsevier Inc. p: 56-467.
(7) Geraci C.J. and Morse J.C. 2008. New species of Cheumatopsyche (Trichoptera: Hydropsychidae) from North Sulawesi, Indonesia.The PanPacific Entomologist 84(1): 1-8.

(8) Berra E., Forcella M., Giacchini R., Rossaro B., and Parenti P. 2006. Biomarkers in Caddisfly Larvae of The Species Hydropsyche Pellucidula (Curtis, 1834) (Trichoptera: Hydropsychidae) Measured in Natural Populations and after Short Term Exposure to Fenitrothion.Bulletin Environmental Contamination and Toxicology 76: 863-870.

(9) Kim J.H., Park J.M., Lee S.B., Pudasainee D.P., and Seo Y.C. 2010. Anthropogenic mercury emission inventory with emission factors and total emission in Korea.Atmospheric Environment 44: 2714-2721.

(10) CCME. 2003. Canadian Water Quality Guidelines for the Protection of Aquatic Life: Inorganic Mercury and Methylmercury. Di dalam: Canadian Environmental Quality Guidelines. Canadian Council of Ministers of the Environment. Winnipeg.

(11) Sudarso J. 2013. Pengaruh Aktivitas Antropogenik Di Sungai Ciliwung Terhadap Komunitas Larva Trichoptera.J. Manusia dan Lingkungan 20(1):68-83.

(12) Kido M, Yustiawati, Syawal M.S., Sulastri, Hosokawa T., Tanaka S., Saito T., wakuma T.I., and M.Kurasaki.2009. Comparison of General Water Quality of Rivers in Indonesia and Japan.Environmental Monitoring and Assessment 156: 317-329. 
(13) Barbour M.T., 2004, Tetra Tech Inc, Owings Mills, Madison, USA). (Komunikasi pribadi).

(14) Yule C.M., and Sen Y.H. 2004. Freshwater Invertebrates of the Malaysian region. Academy of Sciences Malaysia. 861 hal.

(15)Akagi, H. and Nishimura H.1991. Speciation of Mercury in the Environment. in: Suzuki, T., N. Imura, and T.W. Clarkson (Eds.).Advances in Mercury Toxicology. New York: Plenum. 53-76.

(16) Lasut M. T. 2009. Proses Bioakumulasi dan Biotransfer Merkuri (Hg) pada Organisme Perairan di dalam Wadah Terkontrol.Jurnal Matematika dan Sains 14 (3): 89-95.

(17) Suryono T., Sudarso Y., Awalina, Yustiawati, Syawal M.S. 2010. Status Kontaminasi Merkuri di Ruas Sungai Cikaniki,Jawa Barat.Limnotek 17(1):37-48.

(18) Novotny V., and Olem H. 1994. Water Quality Prevention, Identification, and Management of Diffuse Pollution. Van Nostrand Rein-hold. USA. 1054p.

(19) Anonim. 2009. Menggali Emas Menabur Benih Bencana. http:/mobile. liputan6.com/?c_id=8\&id=74905. [diakeses tanggal 24 Maret 2009].

(20) Scroeder W.H., and Munthe J. 1998. Atmospheric Mercury an Overview. Atmospheric Environment 32 (5): 809-822.

(21) Camargo J.A.. 1991. Toxic Effects of Residual Chlorine on Larvae of Hydropsyche pellucidula (Trichoptera, Hydropsychidae): a Proposal of Biological Indicator.Bulletin Environmental Contamination and Toxicology 47: 261-265.
(22) Sinaie M., K.D. Bastami, M. Ghorbanpour, H. Najafzadeh, M. Shekari, S. Haghparast. 2010. Metallothionein biosynthesis as a detoxification mechanism in mercury exposure in fish, spotted scat (Scatophagus argus).Fish Physiol. Biochem. 36:1235-1242.

(23) Devlin E.W. 2006. Acute Toxicity, Uptake and Histopathology of Aqueous Methyl Mercury to Fathead Minnow Embryos.Ecotoxicology 15: 97-110.

(24) Chavan V.R. and Muley D.V. 2014. Effect of heavy metals on liver and gill of fish Cirrhinus rigala.International Journal of Current Microbiology and Applied Sciences 3 (4):277-288.

(25) Sola C, and Prat N. 2006. Monitoring Metal and Metalloid Bioaccumulation in Hydropsyche (Trichoptera, Hydropsychidae) to Evaluate Metal Pollution in a Mining River, Whole Body Versus Tissue Content.Science of the Total Environment 359: 221231.

(26) Niimi A.J. and Kissoon G.P. 1994. Evaluation of Critical Body Burden Concept Based on Inorganic and Organic Mercury Toxicity to Rainbow Trout (Oncorhynchus mykiss).Archieved Environmental Contamination and Toxicology 26: $169-178$.

(27) UNEP. 2013. Global Mercury Assessment 2013: Sources, Emissions, Releases and Environmental Transport. UNEP Chemicals Branch. Geneva. Switzerland. 
(28) Sudarso J. 2012. Keterkaitan Masukan Bahan Organik dan Logam Merkuri Terhadap Struktur Komunitas dan Produktivitas Sekunder Larva Trichoptera di Sungai Ciliwung (Jawa Barat), Desertasi, Institut Pertanian Bogor. Bogor. 134 Hal.
(29). Pirrone N., Cinnirella S., Feng X., Finkelman R. B., Friedli H. R., Leaner J., Mason R., Mukherjee A.B., Stracher G., Streets D. G, Telmer K. 2008. Global mercury emissions to the atmosphere from natural and anthropogenic sources. In Nicola Pirrone and Robert Mason (Eds.), Mercury fate and transport in the global atmosphere: Emissions, measurements and models. New York: Springer Science \& Business Media, LLC. 1-47 pp. 